Shams University in Cairo, thinks that more than 7-million hectares of desert could potentially be reclaimed. "But is there enough water, specifically ground water, available?” he asks.

Egypt's annual water supply per person is around $660 \mathrm{~m}^{3}-340 \mathrm{~m}^{3}$ below the UN definition of water scarcity.

By 2030, it's expected to breach the $500 \mathrm{~m}^{3}$ barrier, below which a country is considered to be facing 'absolute scarcity'. Since the late 1980s, reclamation schemes have depended on Nile water for irrigation. Canals were built to transport fresh water to the plots, but this meant the fields had to be located close to the river. The 1.5 Million Feddan Project, announced in December 2015 by President Abdel Fattah alSisi, will instead rely mostly on groundwater extraction. The ultimate goal is to transform nearly 4-million feddans (an Egyptian unit of area roughly equivalent to $0.4 \mathrm{ha}$ ) of the Western Desert into fertile agricultural land. But only a small proportion of land is located near enough to the valley to be irrigated by Nile water. The rest will use ground water, such as from the Nubian Sandstone Aquifer System, which is one of the world's largest fossil aquifers and lies beneath the Western Desert as well as parts of Sudan, Chad and Libya. Official usage figures are not publicly available, but according to a European Union assessment from 2013 seen by Nature, $86 \%$ of the initial 428,000 ha of new agricultural land will be irrigated with ground water from the Nubian Sandstone Aquifer System. The reclaimed land is expected to require 4.4 billion cubic metres of extracted ground water every year.

The sustainability of pumping such a large volume of water for agriculture is a source of much debate in Egypt. The water in the aquifer is non-renewable, and data on the exact amount of water contained in it are outdated and vary significantly from one study to the next. "Only a pre-feasibility study was conducted prior to the project, not a proper feasibility study," says Gamal Siam, an agricultural economist at Cairo University.

Abou Hadid is convinced that the country should be making use of these resources. "We should not be wary to utilize ground water," Abou Hadid says. "We need to ensure that reserves last at least 50 to 100 years," he says. By that time, Abou Hadid thinks that the cost of desalination technology will have fallen low enough to take up the strain. But such a drop in cost is far from certain. According to Hosam Shawky, director of the Egyptian Desalination Research Center of Excellence in Cairo, the country currently desalinates $250,000 \mathrm{~m}^{3}$ of seawater per day, at a cost of 6 Egyptian pounds (US\$0.3) per cubic metre. "Before desalinated water can be used for agriculture, the price per cubic metre would need to drop to 1.5 Egyptian pounds," Shawky says. "We will need to have a desalination breakthrough, and manufacture all parts locally," he says. Shawky expects the production of desalinated water to triple in the next three years.

Even if the aquifer supply does hold out, cultivating the desert using ground water is an expensive endeavour. Alvar Closas, a groundwater management researcher at the International Water Management Institute in Cairo, estimates that it costs ten times more than farming in the fertile valley and delta. Some wells must be dug as deep as 1,000 m to reach good-quality water, and drip and sprinkler systems are needed to irrigate crops. Furthermore, Closas says, in some locations, extracted ground water is so ferrous that it needs to precipitate into man-made basins before it can be used to irrigate the fields. "Investors have to build high towers to elevate the water, which then trickles down into cooling basins, because it is scalding hot and cannot be applied directly on the field," he says. This increases costs dramatically, and is only affordable for large commercial farms. These up-front costs contradict the argument for reclaiming the desert to move a large section of the population out of the Nile Valley and Delta, says Hanne Kirstine Adriansen, a human geographer at Aarhus University, Denmark, who has studied Egypt's desert reclamation schemes. "Small landholders are cash strapped," she says.

\section{EVERY LAST DROP}

Dalia Gouda, a water-management consultant in Cario, doubts that reclaiming the desert will be sufficient to improve food security for the Egyptian people. "The majority of reclaimed land is given to big, private investors who export most of what they grow," she explains. Part of the 1.5 Million Feddan Project will involve the construction of greenhouses on 42,000 ha of desert. Mahmoud Medany, president of the Agricultural Research Center (ARC) in Giza, devised the proposal for the future greenhouses. He says that the target is to export at least $70 \%$ of production. But unlike Gouda, he thinks that the project will improve food security in Egypt. "You need one worker per acre of greenhouse agriculture. So if 100,000 workers receive a good salary, it enables them to purchase food from the market," he says.

Siam is unconvinced of the food-security benefits of the 1.5 Million Feddan Project. "Food security can only be achieved by growing basic food staples, like wheat and other cereals," says Siam. He doubts that growing wheat, maize (corn) or berseem (Trifolium alexandrinum; used for grazing) would be economically feasible in the desert, and expects farmers to opt instead for vegetables, which provide a quick return on investment rather than subsistence. Gouda agrees. "If you are a poor farmer, the only thing you can afford to grow in the desert are fruit and some vegetables," she says.

Siam thinks that the priority, instead, should be improving the productivity of the existing farmland. Over the past 15 years,
Hadid, a former Minister of Agriculture for the Egyptian government who is now at Ain 


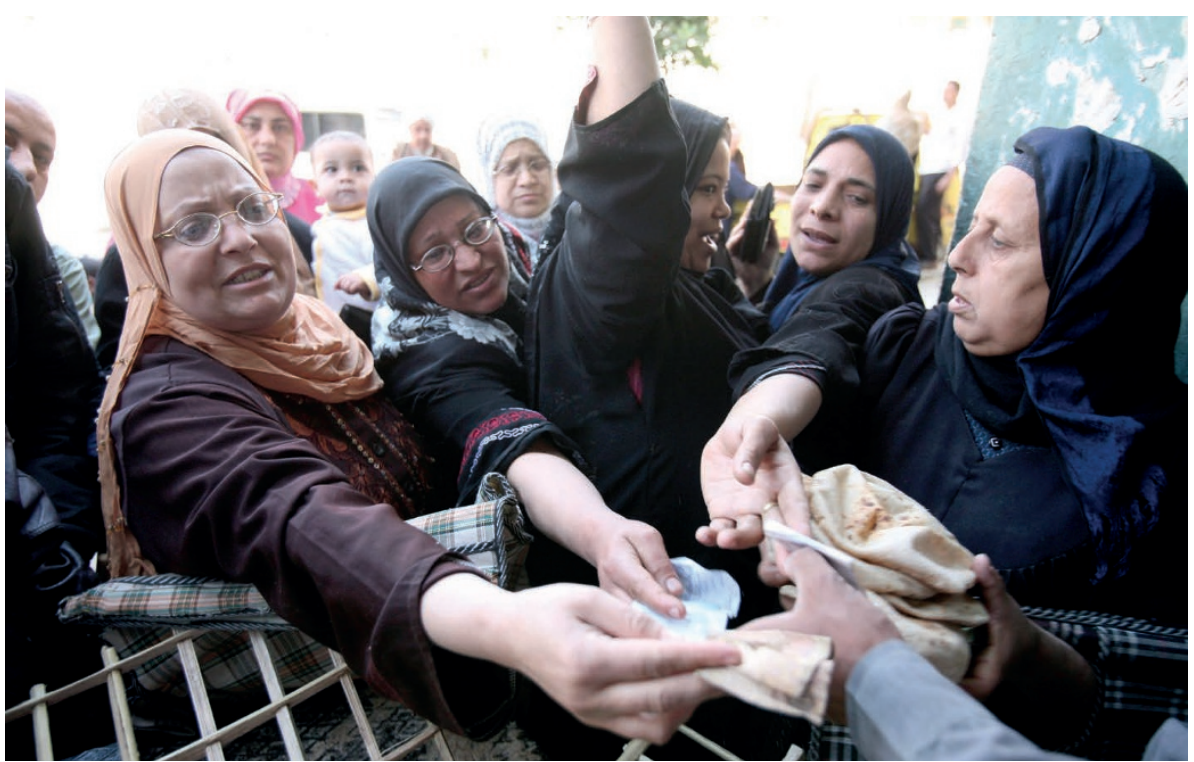

People queue to buy government-subsidized bread — bread is the main source of calories in Egypt.

researchers at the ARC have generated more than 300 new cultivars and hybrids that are able to withstand higher temperatures and increased soil salinity. The new varieties have increased yields of $55 \%$ for cereals, $46 \%$ for legumes, $24 \%$ for oil crops and $20 \%$ for grazing crops. But the centre's funding has been cut significantly in recent years, from the equivalent of $\$ 1.1$ million in 2015 to just $\$ 170,000$ last year, according to Siam.

Despite tough financial circumstances, the ARC and other groups around the country are working to boost the productivity of the land that is already cultivated. Water use is a key concern in the valley and delta, as it is in the desert. The International Center for Agricultural Research in the Dry Areas, the ARC and others are helping farmers to reduce their use of water, fertilizers and seeds, and to increase wheat yields, by developing machinery that means farmers no longer need to prepare raised beds manually.

Raised-bed farming involves digging long furrows to distribute water evenly and planting crops in rows between the furrows. Using this technique, crops receive more sunlight and produce higher yields for less water than flood-irrigation farming, which is widely practiced in Egypt.

The technology can be fitted to a regular tractor, and prepares and sows one feddan in 30 minutes, saving farmers both time and the cost of hiring labourers. So far, the machine has been used on around 3,000 ha of wheat in the province of Sharqiya, where $35 \%$ of domestic wheat is produced. "The mechanized raised-bed technology saves on average $625 \mathrm{~m}^{3}$ of water per feddan per wheat season, which amounts to 4 million cubic metres of water saved per year," says Atef Swelam, a water-management scientist at International Center for Agricultural Research in the Dry Areas .
The Ministry of Agriculture is encouraging farmers to adopt manual or mechanized raised-bed techniques as part of its National Wheat Campaign. Although there is no direct incentive for farmers to cut down on water consumption (irrigation water is free in Egypt), because many farmers resort to diesel pumps to supply water to their fields, the raised-bed technique eases farmers' overall costs.

The government also hopes that water wastage can be minimized. About $30 \%$ of the water destined for irrigation is lost through seepage and leaks from "The majority ageing infrastructure of reclaimed land is given to big, private investors who export most of what they grow." rates. Of the 55.5 billion cubic metres of Nile water allocated to Egypt try shares the resource with Sudan), agriculture uses $85 \%$. The losses are, therefore, enormous.

The Farm-level Irrigation Modernization Project, established in 2013 with funding from the World Bank, the French Development Agency and the Egyptian government, is designed to reduce water loss and boost production by replacing existing irrigation canals with plastic pipes. The earthen primary, secondary and tertiary irrigation canals are susceptible to intense evaporation in high temperatures. "Since the 1970s, the canals' maintenance has been operated by excavators," explains Gouda. Repeated dredging has widened the canals over time, exposing a larger surface to evaporation. By replacing the canals with a buried network of pipes, water loss has been eliminated and farmers' land acreage increased by $5 \%$. "So far, we have installed this new irrigation system on 100,000 acres of land, and the objective each year (the coun- is to cover a quarter of a million acres by the end of the project," explains project leader Mohamed Samir Abo Soliman at the Soil, Water and Environment Research Institute in Giza. "This project is meant to increase water efficiency to $75 \%$, which would increase our water budget by $8-10$ billion cubic metres a year," he says.

\section{BEYOND PRODUCTION}

As in much of the world, food loss is an issue in Egypt. "Of the 30 million tonnes of fruits and vegetables produced in Egypt every year, $40 \%$ is lost," says Siam. Inadequate handling, packaging, transportation and refrigeration all contribute to waste. Unrefrigerated flatbed trucks carrying overflowing crates of fruit and vegetables often cover distances of around 900 kilometres, layering the produce in dust and slowly baking it in the hot Egyptian Sun. "If we addressed those losses, we could increase self-sufficiency tremendously," Siam says.

Various interventions to minimize loss and change consumption patterns have been introduced in the past five years. Food Loss and Waste Reduction and Value Chain Development for Food Security in Egypt and Tunisia, for example, was launched in March 2016. The Italian-funded project focuses on reducing losses post-harvest, and during trading and processing.

And, in 2012, with the support of the Italian Development Cooperation, the UN Food and Agriculture Organization (FAO) launched a package of interventions in five areas of Upper Egypt where malnutrition and child stunting are most prevalent. "We set up community nutrition kitchens for women in 15 villages, and once a week, 20-25 women would gather and cook together under the supervision of a nutrition expert to teach them best practices," explains the FAO's Zahra Ahmed, who managed the project. Women were given advice on how to stretch their food budget to cover the whole month, and the project focused specifically on women with infants. "A lot of literature highlights the importance of good nutrition in the first 1,000 days of life," she adds.

Such interventions downstream of production have the potential to improve Egyptian food security, but for now the idea of carving fertile agricultural land out of the barren desert remains in vogue. Gouda thinks there is another way to make use of the desert, however: to relocate industries and factories there.

Adriansen agrees: "It seems strange that you would move people into the desert to cultivate it, since desert soil is so infertile. It would make more sense to try and move the industry into the desert and use the very fertile land around the Nile to grow food." -

Louise Sarant is an freelance science and environment writer in Cairo, Egypt. 